\title{
Learning through transitions: The role of institutions
}

\author{
Tania Zittoun \\ University of Neuchâtel, Switzerland
}

\begin{abstract}
In this paper two models are proposed for analysing transitions in education. Firstly, transitions are the processes that follow ruptures perceived by people. They include learning, identity change, and meaning making processes. Secondly, processes of change are observed through a semiotic prism, articulating self-other-object-sense of the object for self, and located in a specific social frame. Transitions are thus analysed as reconfigurations of such semiotic prism. The paper proposes to highlight the role of institutions as social frames likely to facilitate, or constrain, such reconfigurations. The role of institutions in transitions is discussed through three case studies: the transition to vocational training, the transition out of a religious school, and the transition to work at war-time.
\end{abstract}

In an approach to psychology admitting the irreversibility of time and the constant changeability of people and their environment, developmental researchers have to define objects of research in which processes of change become particularly salient. There is a long tradition in psychology to study moments of change or ruptures (Dewey, 1910; Peirce, 1877; Schutz, 1944), crises (Erikson, 1975), or disequilibrium (Piaget, 1974), sometimes based on reference to dynamic systems (for ex., Van Geert, 2003). The basic idea is that, in a situation of regular functioning, a disruption of the usual processes catalyses adjustment and calls for the production of newness. New forms of conduct can thus emerge. In some cases these might involve a restructuration of the whole system. Processes following ruptures seem particularly interesting for psychologists: they thus study task resolution, conflict solving, coping, resilience, construction of new schemes, etc. Here, I will call such processes, processes of transition; these are minimally oriented towards a new form of equilibrium, or renewed regular functioning.

Developmental psychologists studying such overcoming of crises or re-equilibration usually hold assumptions on what sort of resolution is "more developmental". As often pointed out, the very notion of "development" suggests some unfolding, towards a "better" state. Any developmental psychologist thus works with some normative assumptions according to which some patterns of change are better than others (Valsiner, 1989; Valsiner \& Connolly, 2003). I 
admit that the quality of a change has to be evaluated so as to take in account both the person's well-being (her sense of agency, her emotional state) and her relative adequation to her social environment. I assume that a change that enables further changes is developmental. A change which leads the person to alienation from the social world, or from herself, limits further changes, and thus, will be considered as non-developmental.

Out of the laboratory, in socially shared reality, ruptures can be caused by events that have different scales, or, as can be analysed after Doise (1982), which depend on various levels of analysis of the social world. Some ruptures are caused by major societal changes, as when a new sickness is discovered (AIDS, as studied by scholars of social representations, Aggleton, Hart, \& Davies, 1989), when a war starts, or when there is an important political change, such as in post-communist countries. Ruptures can be caused by a person's social relocation and change of frame of activity, for example when moving house, starting a new job, or having her workplace restructured. A rupture can come from an alteration in significant relationships, such as separation or birth, or can be for intrapersonal reasons, such as when one decides to abandon religion. In this paper, we will concentrate on ruptures due to a change of frame of activity. However, although most people are affected by social relocation, some people are very used to move around the world and such changes are part of their routines. Therefore, apparent causes of changes - from an observer's point of view - are not necessary perceived as ruptures by a person under study.

As a developmental psychologist, I consider the person in her uniqueness, as she has an interiority (a zone of dynamic and dialoguing thoughts, feeling, wishes, hopes, memories, which belong to her sense of self, and is inaccessible to others), a basic need for self-continuity and consistency. This person is an intentional agent, and needs to confer sense on what happens to her. This person is also located in the social field, where she interacts with others and objects; these interactions can be analyzed as exchanges of a semiotic nature (Valsiner, 1998). Settings of interactions are themselves socially and symbolically regulated, and located in a particular time and space (Perret-Clermont, 2004). These situations and the person are thus acting in a complex fabric of semiotic streams. With such basic assumptions, psychological change is interesting as long as it affects the person's potential conduct - her ability to feel, think, act and interact. As a consequence, we will here examine ruptures that appear as relevant from the perspective of the person.

\section{Ruptures and transitions: Three interdependent processes}

This paper examines events which are perceived as ruptures by the persons themselves, and it focuses on the transition processes which follow. In learning and developmental research, three interdependent processes of change are usually distinguished: identity processes, knowledge acquisition, and sense making, which I consider all to be transition processes (Perret-Clermont \& Zittoun, 2002; Zittoun 2006a,b; Zittoun, Duveen, Gillespie, Ivinson, \& Psaltis, 2003).

Firstly, transitions involve changes in the social, material or symbolic spheres of experience. Transitions imply processes of repositioning, or relocation of the person in her social and symbolic fields (Benson, 2001; Duveen, 2001). Each of these movements can create new goals, orientations, possibilities, constraints on action or losses (Baltes, 1997; Valsiner, 1998; Valsiner \& Lawrence, 1997). Relocations bring the person to occupy positions formerly occupied by others, (Gillespie, 2007); they also confront a person with others, whose reactions mirror that person's changed location. Thus, through one's own apprehension and through the mediation of others, repositioning implies transformations of identities. Identity change is emphasized by Erikson's (1968) analysis of crises and subsequent developments.

Secondly, people's relocation might need social, cognitive and expert forms of knowledge and skills. Living in a new country requires speaking a new language, becoming a mother demands parental skills, working in a new company calls of an understanding of the 
informal social rules, etc. Studies approaching identity in terms of position and interested in the construction of membership, such as Berger and Luckman's analysis of secondary socialization (1966), Coulon (1997)'s work on becoming a student, show the skills required to be able to behave as a member of a given group, and to be validated as such by others. The other way around, socio-cognitive approaches to learning have shown the deep interconnections between identity and knowledge. For example, researchers can manipulate students' task-performance by manipulating their identity status and visibility (Monteil, 1989); children's as well as adults' commitment to learning and solving tasks can also depend on their mutually acknowledged social status (Muller \& Perret-Clermont, 1999; Perret-Clermont $\&$ Nicolet, 2001) or gender (Psaltis \& Duveen, 2006).

Thirdly, through these relocations, encounters with others and learning, the person might be brought to engage in sense-making, that is, to confer sense on what happens to her (Bruner, 1990, 1996; West, 2006). Sense-making comprises processes of elaboration of emotions and experiences through the mediation of signs, among which, but not only, verbal language (Zittoun, 2006a).

Processes of identity, learning and sense making are necessarily linked and are present in all transitions following ruptures perceived as such. Learning difficulties can often be analyzed in terms of the task lacking sense (Rochex, 1995) or of conflicting identities. In turn, to support adult learning, techniques based on elaborating life stories precisely aim to endow new knowledge with a personal sense (Dominicé, 1985).

\section{A model for analyzing situated ruptures}

What models do we have for representing a person's processes of transitions, so as to capture their significant dimensions? The person living ruptures is here considered in her social worlds - in interactions with others, material objects, and symbolic elements. Classically, two types of models represent this sociality of human conduct.

On the one hand, for a century, a metaphor commonly used in a developmental psychology aware of the social embeddedness of human change is the triangle, articulating person, other and object (Mead, 1932; Moscovici, 2003, etc.). The metaphor has been expanded in various ways by psychologists feeling its limitations, who added poles to figure tools, signs, or communities (see Zittoun, Gillespie, Cornish, \& Psaltis, 2007, for a critical overview). In our work, we have proposed to turn the triangle into a semiotic prism metaphor having four corners: the person, an other (real or imaginary, specific or general), a symbolic object (which has usually a socially shared meaning) and the personal sense of that object for the person (Zittoun, 2006b). This model attempts to represent at a glance both interpersonal processes and intrapersonal (or intrapsychic) ones, as psychological change is mostly enabled by dynamics articulating interpersonal and intrapersonal processes (Valsiner, 1998; Vygotsky, 1934; Zittoun et al., 2007). The model compresses dynamics which can be deployed over time. In the model, interpersonal dynamics are represented by the vector going from person to other, and from person to object. Intrapersonal processes are represented by the vector linking person to sense-of-object for person. The idea is that the person has to adopt different positions oscillating through time. From an initial position, the person engages in decentration processes which might lead her to confer sense to the object. She also has to re-distanciate herself from the object, so as to be able to name it, signify it, and eventually, to communicate about its meaning to other. Finally, this model represents the three dimensions of transitional processes: identity positioning is related to the person-other axis; knowing is related to the person-object axis; and sense-making is related to person-sense of the object axis. Additionally, as we will see, the other-object axis represents meaning (socially shared meaning of the object), and the other-object's sense represents acknowledgement, that is, how other person gives the legitimacy to feel or think his or her thoughts. 


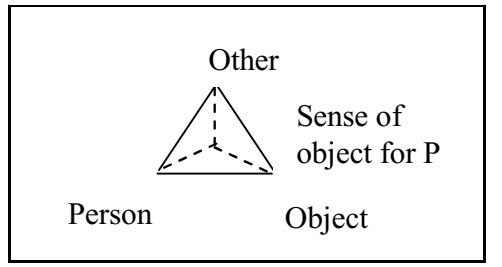

Figure 1. Semiotic prism

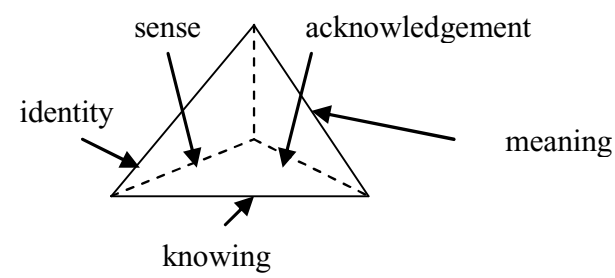

On the other hand, authors have tried to account for the social embeddedness of human conduct by representing inclusive fields. Bronfenbrenner (1977) proposed a model of a system of inclusive spheres of actions; authors inspired by Goffman (1975) or Lewin's (1951) work became aware of the frame or the setting of an interaction, as these are fully part of the conduct taking place (see Grossen, 2000; Grossen \& Perret-Clermont, 1992). Perret-Clermont (2001, 2004) proposed the metaphor of the "thinking space" to designate the dimensions entering in a person's elaboration of sense, which all might be enabling or constraining. The thinking space represents the person in interaction with others, but also the frame in which these interactions take place, and the "frame of the frame", made out of institutions, traditions, cultures, which are all shaping the frame, and interactions, roles, identities, knowledge processes taking places within. The institutions, traditions, culture, are not understood as "boxes" including each other, but rather, as frames from which specific semiotic webs are crossing and constituting the fabric of the thinking space. Traditions produce semiotic webs which are long lasting, and affect many people who have little power to change them. In contrast, a given interpersonal relation is shaped by semiotic exchanges which concern a few persons who can constantly negotiate them. The metaphor thus designates a space which is both social and mental.

We have attempted to locate our prism in such framing, so as to figure its necessary social constitution. In such a model, where would change occur? Change can be seen as linked to the reconfiguration of the elements constitutive of the semiotic prism, and of their respective relationships - a change of the relationship of the person towards the other, the transformation of the sense of the situation for the person, and consequently, of the object for her, etc. (see for example Psaltis 2005, for the idea of reconfiguration). Through such reconfigurations, something radically new can also emerge. Thus, in the limits of these models (prism and frames), if a rupture can be seen as a change in the setting of given human conduct then the transitions designate the processes whereby one situated-prism configuration for a person is transformed into another one.

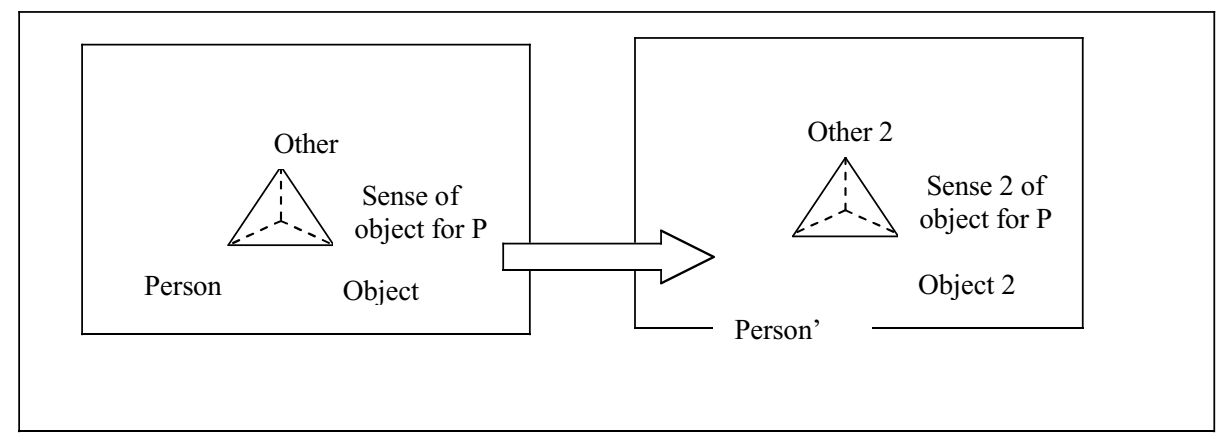

Setting 2

Figure 2. Transition: reconfiguration of the prism 
In such a model these two states of the prism are two moments of a slowly, constantly evolving figure, through the transformation of poles and relationships. Probably, however, some configurations have a relative stability: people have recurrent mediated relationships to certain specific other people (e.g., a good friend with whom one shares a passion for cinema), or to a generalised other (e.g., science teachers, towards whom the person might always feel stupid when addressing equations). On the basis of such a model, our aim is to deepen our understanding of processes taking place in transitions, that is, dynamics leading to reconfigurations of the prism or to the emergence of newness. A developmental change would be a change which is part of a generative movement - reconfigurations lead to new reconfigurations, etc. Yet constraints on such processes might be due to any constituent of the situation: the presence of an other, his or her acceptance of the sense of object for the person, the capacity of the person to transfer some understanding or relationship from one setting to the other, etc. In particular, as we are here interested in learning and education, we will question the role of the frame, in particular institutional settings, in these reconfigurations.

In this paper, we thus will consider a series of case studies: that of former school dropouts starting a vocational training, that of religious young people coming to secular life, and that of a young woman becoming a land-worker in a time of war. We will first analyse them with the model proposed here and thus ask: What are the constituents of the situations? What is changing? What it is that facilitates such reconfigurations? What it is that constrains them? Second, we will try to highlight the role of formal institutions in the facilitation, or the impediment, or transitional processes.

\section{Case studies for knowledge building}

Methodologically, studying transitions raises a classical issue: how to capture change? Here we want to consider real-life relocation which involves reconfiguration of framed selfother-object-sense prisms. The case studies have been documented through two main available techniques: real-time data gathering, and reconstructive ones (that is, aiming at reconstituting evolving events in the past on the basis of semiotic traces). For the school drop-outs, school ethnography has enabled real-time observations and is combined with reconstructive interviews; interviews with young religious people are reconstructive, and completed by participation to the Jewish community; and we use the land-worker's diary as data. A third technique, not used here, consists of recording interactions and decomposing them in their micro-processes (see for example de Saint-Georges \& Filliettaz, this issue; Grossen \& Oberholzer, 2000; Psaltis \& Duveen, 2006). Time-located processes can thus only be approached, not captured. We have completed such data with additional information, about a person's immediate social others, the actual material and symbolic environment in which she is, etc.

Case studies enable the observation of complex situations; they authorize theoryquestioning, expanding and building. When a series of case studies are brought together on the basis of their theoretical equivalence, a theory has to be transformed so as to be able to account for these cases, both in terms of their specificities and their similarities. Of course, at some degree of generalisation, a model thus constructed loses some aspects of complex cases. However, well-documented cases offer rich data which is available to interested researchers (Stiles, 2005; Valsiner \& Connolly, 2003). In what follows, given space restriction, I will describe each of the three settings, highlight the transitional processes of one young person, and attempt to understand the specific role of the institutional frame.

\section{Case 1: Pre-apprenticeship}

In Switzerland, young people in situations of failure at the end of compulsory school, 9th grade, aged 15 , have as their only option to enter the job market as non-qualified workers. In a 
country in which $80 \%$ of the population has a professional training, and where continuous education is highly encouraged, the competition is high; for a young person, it is much preferable to enter the job market after an apprenticeship. An apprenticeship is a certified vocational training on a dual model, during which a student spends $40 \%$ of the week at school to learn technical as well as basic disciplines (mathematics, languages, etc.), and the remaining $60 \%$ in a firm. In order to enter such training, a student must have successfully concluded compulsory education and have been accepted as apprentice in a firm. Thus, students who failed compulsory school cannot start such training, and firms would not want to take them as trainees. As last attempts to avoid social exclusion for these young people, many local initiatives propose a 10th year of education, a last chance to ameliorate their grades. However, such initiatives often have poor results, partly because young people who have had a "failure-track" have no interest in investing one more year in school.

In the 90s, years of European economical recession, the situation of such school dropouts was even more risky, because firms tended to become very selective in accepting personnel. Non-qualified young people were thus at high risk of social exclusion. In that context, we have been contacted by the Centre for professional training of the Neuchâtel littoral (CPLN), who had developed a one-year program which had surprisingly good results $80 \%$ of their students could indeed start an apprenticeship, that is, raised their grades, and were chosen as apprentices before other young people with much better school trajectory. $\mathrm{We}^{1}$ were thus asked to analyse that success. I spent about a year in the school and in the classrooms, interviewed the coordinator of the school sector, the psychologist, the director, teachers, as well as current and former students. The following picture emerged (see Zittoun, 2004, 2006a).

The one year program, called "pre-apprenticeship" was designed as a "last-chance" and only students who had no other chances to start an apprenticeship were accepted. The coordinator, who reorganised the sector, thought that the only way to mobilize the students in learning was to provoke a rupture with their previous school-experience, during which bad students carried their reputation from year to year, were ultimately ignored by teachers, and progressively abandoned by their parents. Thus, before the school year starts, teachers require from the students to find a trainee place before they even start the program. Students are often for the first time placed in an agentic, challenging situation; hence they arrive in the school with this first success (how these trainees are accepted by firms will be described below).

At the beginning of the school-year, the coordinator explicitly imposes the following: none of the teacher has access to the files and the past grades of the students. No student is thus judged on the basis of his past reputation. The coordinator makes explicit the inversion of values that his school proposes: "people always told you that you weren't good at school matters; now, it is your chance to show what you are good at"! A highly defined and structured social frame is then established: schedules, behavioural rules, are made extremely explicit. The model is that of firms: students start very early in the morning and have demanding schooldays; the annual schedule is constantly recalled. However within this frame, a high-quality relational network is established: meeting opportunities and communication channels enable each teacher to have information about students' experiences in other classrooms, in the workplace, or in the families. The school is careful to involve parents in their children's training, for example by translating communications in the many languages spoken by them, encouraging them to call teachers, asking them to help students to find an apprenticeship place for the following year, etc. Yet this frame has two more specificities.

Firstly, the coordinator and director do an important work of connection with the town's firms. They present their program to local entrepreneur's associations such as the Kiwanis clubs. They also present it through the media - TV, radio and newspapers. The message is thus to "give a last chance" to these young people. It is thanks to such networks with the economic milieu that students eventually find their training place. Secondly, the coordinator enquired about the skills required by potential employers. He recounts that he initially asked chiefs of companies what they were looking for when hiring apprentices; they answered: grades. So the school made some effort to raise the students' grade, with no success in terms 
of them being hired as apprentices. The coordinator then realised that firms where looking at the actual conduct of young people as they came to visit the firm or as trainees: how 'handy' they were, how good an impression they gave, how much initiative they had... much more than how well they knew mathematics or German! So the school decided to reinforce such skills in young people. Within the tight frame of the national curriculum, the school rearranged the courses offered to students. Teachers thus established activities aiming to develop implicit social knowledge, technical skills, and thinking heuristics. Implicit social knowledge refers to implicit codes to which these young people often do not have access given their family background: not speaking to an adult when chewing gum, wearing clean clothes before an interview, etc. Such knowledge was partly developed in the setting of a course in "office technique" through role-play, peers comments, informal jokes, etc. Technical skills include how to prepare and serve a proper coffee, or how to change paper and ink in the copying machine, and were taught by invited specialists. Thinking heuristics concern the ability to elaborate $a s-i f$ scenarios which help to prepare for the future. During one-to-one supervisions, the coordinator guided thinking procedures, for example guiding the student's preparation to a job appointment: at what time one has to be there, so at what time one has to leave home to catch the bus, what to do when one arrives at the company, etc. What about classical school knowledge? Rather than aiming to bring students to a full understanding of the subjects, the school privileges efficiency at exams: teachers propose repetitive training of right answers, and often teach "tricks" which will enable students not to be disqualified. The efficiency of the program seems thus located at various levels: the students learn to behave properly in the workplace and to master implicit knowledge (skills); this triggers acknowledgment by adults; and, in turn, it supports the students' self-confidence (identity). Through this, young people progressively become able to sketch a realistic professional project, which can be linked to past experience, and might lead to practicable action (sense). See for example the following student's narrative.

Tatiana is going to start an apprenticeship as hotel assistant. She explains that she initially wanted to become a photographer but realised the difficulty of finding a job. At the end of compulsory school, she went on training as receptionist in a hotel, and said to herself, "that's my dream, to become a receptionist". That experience could indeed be linked to her past, "it is true, I love luxury since I am a child; it was a dream". It can also take some value in relationship to her current young woman's taste:

It is the only job in which you are all the time in contact with many people, where you can travel (...) I love to work at night, to have mornings off, to have irregular schedule; to be free when others work, to work on weekends but still be able to go dancing afterwards.

Tatiana started her pre-apprenticeship thinking that it would lead her to become a receptionist, an object which made sense for her, in link to her past and tastes. However, during the one-year program, she was brought to realise - probably by a teacher - that the position of receptionist required some additional secondary school training that was out of her reach. She thus had to readjust her dreams to actual constraints, and thus decided to start a hotel assistant apprenticeship which does not require such additional training. However, this forced reconfiguration does not prevent Tatiana from conferring a new sense on that new object:

I wanted to do a short apprenticeship, so that I can do many things after. That lasts two days, and then you can climb up. You never stay at the bottom. For example, the director of a great hotel was initially a cook - that's crazy!

How can we understand the transition that occurred here? We have little information about Tatiana; but we might propose that in a previous setting, she was taken in a prism linking her to her training as hotel receptionist (object), and possibly, an idealised other - a 
receptionist that lives in luxury and travels around the world,- thus making sense in relationship to her childhood dreams. However, in the new frame proposed by the school, we might make the hypothesis that the prism was reconfigured thanks to the intervention of others - coordinator, teachers, an employer. Such others brought her to realise the mismatch between the social demands (meaning) of the professional training (object). The object is thus replaced by another one, "hotel assistant", for which Tatiana's skills seem validated. That object, less prestigious than receptionist, is however not damaging for her self-identity. On the contrary, Tatiana is able to link this project to a new other - the hotel director who initially was a cook - and thus, through imagination, to give a personal sense to that change: it still suits her present life-style.

In these progressive reconfigurations, the institutional setting plays an essential enabling role. It is designed to create a rupture; it is strongly structured while enabling a welcoming thinking space, in which adults help the young woman to adapt her dreams to the demands of the socially shared reality; it finally establishes bridges to the job market to facilitate the concretisation of projects. Not only is the institutional setting designed to support transitions, but also, Tatiana seems to be able to use it as an essential social resource: she can rely on it, adapt to it, and she is accompanied by it when she has to leave it.

\section{Case 2: Returning from Yeshiva}

A second example is given by the case of Jewish religious young people entering a secular university program, after having been for one or two years in a rabbinic school in Israel (Zittoun, 2006c). Data has been collected through my participation in the activities of a University Jewish community, as well as interviews with young people in the frame of a research on "the place of culture in transitions" (Zittoun, 2006b). The young people considered here grew up in Jewish religious communities in England, relatively protected from non-Jews. After secondary school, they spent one or two years in Israel in a Yeshiva, a rabbinic school, as most of the young men and some young women of their generation from their social milieu do. Such inclusive schooling is fully organised around the study of the texts of the tradition [the Torah (the Bible), the Talmud (religious legislation and its commentaries)], prayers, as well as the accomplishments of good actions. For a religious person, study and prayer are ways to ameliorate oneself and to honour God. Days, weeks and months are structured by religious life: prayer and study time, rest and meals, rituals and holidays. Yeshiva also offers a strong feeling of community of faith and fate, emotional support and emulation; practical matters - cooking, laundry, etc. - are taken care of by others. Thus, in this setting, people are given a space to live accordingly to their set of beliefs and commitments.

After one or two years in this protected environment, young people are called back to England by their families, who want them to study at university to get a profession. The religious young men I met described this move to England as a "split", an experience which remained painful for a long time. Coming to secular life and studies can thus be identified as rupture; it is perceived as strong by these persons. This might be for a number of reasons. Firstly, many young men did not want to leave Yeshiva, but did so under their parents' request; secondly, it was reported that some rabbis at the head of the Yeshiva were encouraging young men to stay there (to become scholars). Thirdly, although Yeshivoth have instituted a whole welcoming setting for newcomers, it seems not to prepare at all young people to leave them (Shaffir, 1997, 2000).

Coming to study in a secular, Christian based University, implies firstly a change of physical setting. There, the returning Jews have to learn to accommodate their religious life to a secular environment, to combine secular studies with religious studies, and to be a minority in a very diverse population. What transitional processes were necessary to adjust to this new setting? Firstly, the Jewish community and the chaplain created daily and weekly shared activity - prayers, study, meals - which created a diffuse frame reminiscent of the Yeshiva, and also, created a "protected space" within secular society. Secondly, if they feared that living in a secular world could endanger their religious identity, young people realised that their religious 
practices were actually reinforcing their identity. As they noticed, by practicing rituals and prayers, one turns oneself into a religious person. A young man saw his heuristics of thinking as identified by a teacher as specifically "legalistic", which is indeed what Talmudic argumentation is. A young woman realised she had a distinctive attitude towards knowledge: literature was approached with the same epistemological attitude as were religious texts, that is, with the idea that the text always has something to teach. Religious knowledge could thus reinforce identity, especially as long as contacts with other Jews were maintained, but also, when confronted by non-Jews: the young people learned to manage their difference and to explain the specificity of their food habits. However, the main issue upon which they had to confer sense is the rupture itself; and for this, it seems, religious knowledge could not be mobilised. This was rather a surprise for me, because the tradition provides people with an infinity of stories as useful metaphors, and with a set of hermeneutic rules which enable one to link any event to a biblical situation. Our interpretation here was that some of the orthodox heads of the Yeshivas had condemned young people's return to a secular life, and thus, had invalidated the possibility of linking objects such as religious texts, with issues relevant to the young person. Interestingly, when young people were asked about other cultural elements which eventually facilitated their transition to secular life, these young people mentioned selfhelp books or novels. For example, Eli had been questioned about his literary choices:

Now, I was talking about this sort of... difficulty somehow in getting a balance between all the aspects of life. The Glass Bead Game [by Herman Hesse] - (...) basically, there is a sort of college on a hill, completely isolated from everything else, where the people there are very involved in a sort of esoteric learning, which is difficult to understand, what [it] is and what sort of impact it has on anything else, and then again on the outside world obviously. And there is one character in it, who is really firmly in one world, and he feels the tension between the one world and the other world. (...) And that, I mean I could really, I really read that, in terms of having been to Yeshiva and coming to University, obviously there weren't exact parallels, but I could relate to that very strongly. Erm - and, I don't think the book actually helped to resolve the conflict, the actual conflict, it didn't really helped, it sort of more.. it demonstrated the differences, I think - but it helped. It is nice to know that other people are thinking the same things you are. (Eli)

In the Glass Bead Game, the main character has been a brilliant student chosen to enter a remote school, where an obscure, but esoteric knowledge is studied. The main character eventually decided to return to the mundane world, and there is a long way for him to define his place there, and the status of his special knowledge. Similarities can be found between Eli's story and the novel: structurally (the return story), semantically (being chosen to be the holder of a rare knowledge), and emotionally (anxiety, pride, and loneliness) a strong resonance between life and text can be created. The text might be emotionally invested, and provides Eli with its transformative structure. Hence, the text offers a narrative line that links two split worlds. The text appears as a symbolic resource used by Eli to elaborate his experience of coming back.

In this second case study, contrary to the first case, the institutional setting of the Yeshiva did not facilitate a young person's departure out of it, firstly by not giving the practical or social resources which might facilitate this, and second, by making the knowledge itself nonusable. In the setting of the Yeshiva, the young people are dealing with an object, the religious text, with the validation of the Rabbi, the other, who helps him to make a personal sense of it, sense which is harmonised with the situational demands, that of becoming a religious, Godhonouring Jew. With the change of setting, the young people have still as object the religious texts as they address the issue to which they have to confer sense - living in secular world. However, the interiorised figures of these rabbis condemn such issues, because they condemn the secular setting. Therefore, the other invalidates the use of the religious object to confer sense on the rupture. It is only after a certain time in the new setting, after the university 
chaplain had created a good enough frame and relationship with the young religious people, that the chaplain could take the place formerly occupied by the former rabbis as significant other. Thanks to his "modern" uses of religious texts, he taught and authorised young religious men to use religious texts to question personally relevant secular issues. Also, after a certain time, young people could, like Eli, support themselves through their transitions by changing the objects, substituting religious texts with literature. With these, they were much freer to question and confer sense on anything relevant to them and not covered by the Bible as they used to understand it. Finally, such relationships to new objects of knowledge enabled some religious Jews to rethink their relationship to others and themselves - that is, their identity. Eli thus explains that he realised that the Jewish tradition also encouraged a balance between religious and secular life, and openness to different people and other forms of knowledge. Thus, not anymore an identity threat, the new sense conferred on different otherness becomes an enrichment of identity. In this second example, then, the first institutional setting, highly structured, seem to prevent transitions out of it. The second is recreating some of the structural condition of the first one, while being also open to the outside. Additionally, once they are in an institution allowing personal exploration, young people find additional symbolic resources for their transitions to complete what is provided by the setting.

\section{Case 3: Living with war}

War imposes major ruptures in people's lives. During World War II, a young woman collected her thoughts in her diary that she sent to the Mass Observation project aiming at documenting people's lives in England (Bloome, Sheridan \& Street, 1993), and which we analysed as part of a collaborative project (Gillespie, Cornish, Aveling, \& Zittoun, 2008; Zittoun, Gillespie, Cornish, \& Aveling, 2008). In such a situation of rupture created by a government, many cultural elements and social supports are intentionally created to facilitate people's lives: official leaflets about specific war-issues (air-raids, shelters), propaganda through posters, radio and films meant to reinforce the morale, adult education (W.E.A), and youth leisure activities such as balls and theatre. The young woman, who we called June, is quite receptive to these various discourses, but really engages with only a few of these cultural elements, which she uses as resources to facilitate her own changes. Also, social exchange and intense discussion with her communities played an important role in her transitions (Gillespie et al., 2008).

June used to live in a tight-knit community on the East coast of England, with her sister and her mother, where she was working at the family's garage. Her leisure was spent at the beach, playing tennis, or reading. As the war starts, her involvement in the Mass Observation project together with her sister immediately locates her as a "mass-observer", a position that she will maintain during most periods of the war. This position is defined in relationship to the half real, half imaginary figure of Tom Harrison, one of the leaders of Mass Observation, of whom she has read the biography and followed each public intervention. His presence also legitimates actions undertaken as war diarist, such as talking to foreigners, visiting places, etc. Together with this identity belongs the project rooted in June's family that a war is only justified if it aims at ending all further wars; and one way though which thus might be done is education - this is where war can make sense. Thus, June engages in W. E. A. classes and summer courses, where she learns about the history of Germany and Italy, European politics, etc. Here, the initial rupture that is war becomes acceptable once the person's identity has changed by becoming a mass-observer, in the 'presence' of the figure of Tom Harrison. The history of Europe and its wars as well as present history (as created through Mass Observation) become resources which confer sense on June's present war experience, being linked into a trans-generational story, as it is mediated by the figure of an idealised Harrison.

Later on, war was made concrete for June, as for all the women in England, through the obligation to join the war-effort, and after extensive discussions with her community; June became a land-worker in agricultural gardens, far from home. Although June is exposed to propaganda justifying such change of setting, which might be used to make it meaningful, June 
rather finds supports in books she borrows from local libraries. She starts to appreciate literary texts which describe the beauty of landscapes, she reads about agriculture, developing her theoretical knowledge which goes with the actions in which she is now engaged. It is through confrontation with others, who are closer to whom she used to be, that June becomes aware of her identity repositioning. For example, as she works as a gardener, it becomes more difficult to attend W.E.A. conferences. However she eventually attends a couple of these and comments:

We resolved to go out in the evening, so caught bus to $\mathrm{G} \&$ went to a W.E.A. class. Economics on [sic] Reconstruction. This class was on Production \& ended up with wholesale condemnation of government $\&$ war failures. There was about 15 at the class a mixed sample of townsfolk. We went in our uniforms of work \& caused quite a sensation with the mud from the soil still stuck to our shoes (02.42).

June's way of talking about these conferences contrasts with her earlier comments. Thus, W.E.A. knowledge, towards which her position has changed, becomes a resource for reflecting and realising her new identity as woman land-worker, in the confrontation with others, non-workers. From an initial, abstract and future-oriented discourse about the end of all wars, June has now a discourse much more concerned with the position of women. She thus reports a meeting with other workers:

Women gardeners on the whole seem to look worse than women teachers. There were about 25 present. It was quite interesting, mainly about the necessity for unity in women land workers now ready for after war. While it was agreed the returning men from the forces would need first consideration for jobs etc the women must not be squashed in agri \& horti culture (01.43).

Indeed, many new experiences lived by June question her initial expectations about what are a woman's normal life, values, work, and relationships with men (Zittoun, Aveling, Gillespie, \& Cornish, in press). This group of discussions might be triggering the emergence of a new narrative and projects for after-war life.

In this third case study, it is less the war as a whole which is felt as rupture, than the various social and geographical relocations through which it becomes concrete in June's life. These require important changes of activity and of social network, and through these, social position, identity, life-orientation and sense conferred on events. For the first transition, as war interrupts normal community life, a first configuration is established, which immediately confers on June a mass-observer identity, under the other that is the director of MassObservation, and which leads her to learning and writing activities (objects) which all add to the sense she confers on war. In the case of the second transition, the reconfiguration starts with the fact that in her new settings, June is mainly busy working in the fields, and thus develops new agricultural knowledge, objects which partly replace her previous preferred objects of knowledge. Through confrontations with new others, she comes to realise that her relationship to her past objects of knowledge has changed, and that her identity is different; so the sense of war is also different.

What has facilitated such transitions? Although the government offers many forms of cultural knowledge intended to facilitate people's adjustment to war, June's resources are quite selective. Her first transition - arising out of war disrupting the local community - is partly supported through June's intense discussions with her relational network. Also, historical knowledge, novels, and films, are used as symbolic resources. The second transition is partly supported through uses of symbolic resources, used in different ways: historical knowledge is used as a resource to question one's social position. Also, shared discussions support changed sense-making. Additionally, the data presented here are based on a young woman's diary: it is likely that writing a diary, quasi-daily over the five years of the war, is in itself a major resource. It provides June with a 'thinking space' and an enduring sense of continuity beyond ruptures; it supports her thought about past and future; through writing, it enables symbolisation and distantiation of experience, and thus self-reflection, etc. (Wiener, 1993). 


\section{Institutions in transitions}

We have attempted to describe three sorts of transition in similar terms. People were facing ruptures which were all somehow imposed - an educational program for drop-outs, coming back from Yeshiva, living in war - but in face of which people had some margin of freedom in terms of reinterpretation: choosing to commit oneself in a last chance year of studies, accepting to open oneself up to the secular world, or choosing one's positions and commitments facing the war. These transitions occur in and out of educational institutions in the two first cases, and within the social space and its state institutions in the third case. The first and second institutions have structural similarities: both probably require people to experience rupture as they enter the institution; they provide a close-knit environment, a strong collective feeling, committed significant adults, and a strongly regulated time and symbolic environment - the first being however not all-inclusive - and strong emotional link between participants. They thus provide mainly two types of resources. The symbolic structure of a social setting (its rules, rites and routines) might become an important social resource as it gives an external frame in which one can feel protected while changing, and which can be partly internalised (Grossen \& Perret-Clermont, 1992). Various modalities of interaction can take place in group discussions and specific relationships with significant others: co-construction, imitation, emulation, etc; such dynamics can promote the work of transition, such as identity-work and learning, and are thus other social resources. The radical difference between the institutions presented in the two first cases is that the first one is openly and mainly organised around people's next transition (that is, their entrance into the work market), while the second is organised so as to retain as much as possible people within a community. The third case has in common with the first its aim to facilitate people's transitions - here, dealing with the ruptures and changes imposed by war. The state institutions thus provide people with various resources which are more or less formal (propaganda, information, adult education, mass media) which aim clearly at supporting people's identities, capacities to act and sense making. These, like the novels in the second case, can become symbolic resources (Zittoun, 2006b).

We can move one step forward and try to understand what, in these three institutions, facilitates or constrains the uses of resources which facilitate transition. Firstly, cultural elements which might become symbolic resources are available and more or less reachable in a given context. The pre-apprenticeship schooling created courses to provide students with skills that they would not have gained otherwise; June reads novels and finds comforts in them as long as she has access to public libraries during war times. Also, the two first institutions tend to promote one discourse, one set of cultural elements, while in war time, the state institutions diffuse many discourses. This plurality of voices invites more reflectivity and conscious use of resources (Zittoun et al., 2008). Secondly, to be actually used, these elements often need to be mediated: specific forms of relationships can thus render these actionable (Cornish, 2004). The coordinator of the pre-apprentices guides and validates all their progress; June discusses with her whole community about the official war-leaflets to decide how to use them; she addresses her diary to the internalised figure of Tom Harrison, who legitimises her writing enterprise. In contrast, Yeshiva rabbis do not symbolically allow using religious texts as resources beyond the Yeshiva, as they do not legitimise secular life. These validations by a significant other address always, at the same time, the identity position of the person (e.g., you can be a mass observer; you can't be an assimilated Jew, you can start a career from the bottom of the scale). The evaluation of an important other can be internalised and will construe the person's identity and sense conferred to events. These identity processes also importantly affect the subsequent skills the person will display or develop in link to a specific object of knowledge: reading novels which support self-reflection, engage in the actual practices of learning in enabling to start an apprenticeship, going to learn agriculture in a Cambridge summer school. Finally, these various framing and interactive effects, as well as identity and sense dynamics, can support, or not, the sorts of processes required for transfer of skills or knowledge from one setting to another one. Indeed, social-spatial transitions might 
require the activation of skills developed in another frame: pre-apprenticeships learn at school skills to serve coffee in the work place, they then have to use them there; religious students learn hermeneutic skills in religious classes, but the challenge is for them to actualise these skills on other sorts of texts.

Thus, institutional dynamics play here a fundamental role: the whole pre-apprenticeship setting is organised towards bringing the students to the professional world, and this through the very modalities of its daily activities; in contrast, as institution, a Yeshiva is usually open to the external world when it aims at welcoming newcomers and facilitates their transitions within the school, but is organised so as to discourage people to leave. This has consequences on people's direct access to, or ability to use resources to support transitions processes.

\section{Transitions in development}

If there is a long tradition of studying ruptures in people's lives to have access to developmental processes, this paper has concentrated on the transition dynamics which might be triggered by such ruptures. It has proposed to see change at the level of reconfiguration of the ever-moving semiotic relationships unifying a person's perspective on a object, the sense it acquires for her, and the meaning it might have for another person, present or in the mind. Such reconfigurations also imply constant readjustments of the person's identity and skills. The interpersonal and intrapersonal dynamics involved in such reconfiguration are always taking place in specific social and institutional locations, which can materially and symbolically constraint and guide the person's change. Thus, if transitions are ultimately the processes through which change and development might occur, then institutions who's aim is to support young people's learning and development should pay a careful attention to the ways in which they support, or not, transition processes within their frame, to their frames, or out of them.

\section{Notes}

1 The Institute of Psychology of the University of Neuchâtel, Switzerland, under the supervision of Anne-Nelly Perret-Clermont.

\section{References}

Aggleton, P. Hart, G., \& Davies, P. (Eds.). (1989). AIDS: Social representations, social practices. London: Taylor \& Francis.

Baltes, P.B. (1997). On the incomplete architecture of human ontogeny. Selection, optimization and compensation as foundation of developmental psychology. American Psychologist, 52(4), 366-380.

Benson, C. (2001). The cultural psychology of self. London: Routledge.

Berger, P.L., \& Luckmann, T. (1966). The social construction of reality: A treatise in the sociology of knowledge. New York: Anchor Books.

Bloome, D., Sheridan, D., \& Street, B.V. (1993). Reading mass-observation writing. Sussex: University of Sussex Library.

Bronfenbrenner, U. (1977). The ecology of human development. Cambridge: Harvard University Press.

Bruner, J.S. (1990). Acts of meaning. Cambridge: Harvard University Press.

Bruner, J.S. (1996). The culture of education. Cambridge MA/London: Harvard University Press. 
Cornish, F. (2004). Constructing an actionable environment: Collective action for HIV prevention among Calcutta sex workers. Unpublished $\mathrm{PhD}$ thesis, London School of Economics.

Coulon, A. (1997). Le métier d'étudiant [The profession of student]. Paris: Presses Universitaires de France.

Dewey, J. (1910). How we think. Lexington, Mass: D. C. Heath.

Doise, W. (1982). L'explication en psychologie sociale [Explanation in social psychology]. Paris: Presses Universitaires de France.

Dominicé, P. (Ed.). (1985). Pratiques du récit de vie et théories de la formation [Practices of life narrative and theories of training]. Genève: Faculté de Psychologie et des Sciences de l'éducation.

Duveen, G. (2001). Representations, identities, resistance. In K. Deaux \& G. Philogene (Eds.), Social representations: Introductions and explorations. Oxford: Blackwell.

Erikson, E. H. (1968). Identity, youth and crisis. London: Faber \& Faber.

Erikson, E. H. (1975). "Identity crisis" in autobiographical perspective. Life history and the historical moment (pp. 17 46). New York: WW Norton \& Company INC.

Gillespie, A. (2007). Becoming other. From social interaction to self-reflection. Greenwich (CT): InfoAge.

Gillespie, A., Cornish, F., Aveling, E., \& Zittoun, T. (2008). Conflicting community commitments: A dialogical analysis of a woman's diaries kept during World War II. Journal of Community Psychology, 36(1), 35-52.

Goffman, E. (1975). Frame analysis: An essay on the organisation of experience. Cambridge MA: Harvard University Press.

Grossen, M. (2000). Institutional framings in learning and teaching. In H. Cowie, V.D. Aalsvort, \& N. Mercer (Eds.), Social interaction in learning and instruction: The meaning of discourse for the construction of knowledge (pp. 21-34). Amsterdam: Pergamon Press.

Grossen, M., \& Oberholzer, V. (2000). Mise en scène d'une leçon de grammaire: Perspectives et variations. Rapport de recherche dans le cadre du PNR39. Berne: Fonds National de la recherche scientifique [The setting of a grammar class: perspectives and variations].

Grossen, M., \& Perret-Clermont, A.N. (Eds.). (1992). L'espace thérapeutique, cadres et contextes [The therapeutic space: frame and contexts]. Neuchâtel, Switzerland/Paris: Delachaux et Niestlé.

Lewin, K. (1951). Field theory in Social Sciences. Selected theoretical papers (Ed. S. Cartwright). New York: Harper \& Brothers publishers.

Mead, G.H. (1932). Mind, self and society from the standpoint of a social behaviourist. Chicago, IL: Chicago University Press.

Monteil, J.-M. (1989). Eduquer et former [Educate and train]. Grenoble: Presses Universitaires de Grenoble.

Moscovici, S. (2003). Introduction. Le domaine de la psychologie sociale [The domain of social psychology]. In S. Moscovici (Ed.), Psychologie sociale (pp. 5-22). Paris: Presses Universitaires de France. (Original work published 1984)

Muller, N., Perret-Clermont, A.-N. (1999). Negotiating identities and meanings in the transmission of knowledge: Analysis of interactions in the context of a knowledge exchange network. In J. Bliss, R. Säljö, \& P. Light (Eds.), Learning sites, social and technological resources for learning (pp. 47-60). London: Pergamon.

Peirce, C.S. (1877). The fixation of belief. Popular Science Monthly, 12, 1-15.

Perret-Clermont, A.-N. (2001). Psychologie sociale de la construction de l'espace de pensée [The social psychology of the constrction of the thinking space]. In Ducret (Ed.), Constructivismes: Usages et perspectives en éducation (pp. 65-82). Genève: SRED.

Perret-Clermont, A.-N. (2004). Thinking spaces of the young. In A.-N. Perret-Clermont, C. Pontecorvo, L. Resnick, T. Zittoun, \& B. Burge (Eds.), Joining society: Social interaction and learning in adolescence and youth (pp. 3-10). Cambridge/New York: Cambridge University Press.

Perret-Clermont, A.-N., \& Nicolet, M. (Eds.). (2001). Interagir et connaître. Enjeux et régulations sociales dans le développement cognitif (2nd edition) [Interacting and knowing. Challenges and regulation in cognitive development]. Paris: L'Harmattan. (Original work published 1986) 
Perret-Clermont, A.-N., \& Zittoun, T. (2002). Esquisse d'une psychologie de la transition [Sketch for a psychology of transition]. Education permanente. Revue Suisse pour la Formation Continue, 1, 12-15.

Piaget, J. (1974). The grasp of conciousness: Action and concept in the young child. London: Routlege \& Kegan Paul.

Psaltis, C. (2005). Social relations and cognitive development: The influence of conversation types and representations of gender. Unpublished PhD thesis. University of Cambridge.

Psaltis, C., \& Duveen, G. (2006). Social rRelations and cognitive development: The influence of conversation types and representations of gender. European Journal of Social Psychology, 36, 407-430.

Rochex, J.-Y. (1995). Le sens de l'expérience scolaire [The sense of school experience]. Paris: Presses Universitaires de France.

Schutz, A. (1944). The Stranger: An essay in social psychology. American Journal of Sociology, 49, 499-507.

Shaffir, W. (1997). Disaffiliation: The experiences of Haredi Jews. In M. Bar-Lev \& W. Shaffir (Eds.), Religion and the social order: Leaving religion and religious life (vol. 7, pp. 205-228). Greenwich, CT/London: Jai Press.

Shaffir, W. (2000). Movements in and out of Orthodox Judaism: The case of penitents and the disaffected. In L.J. Francis \& Y.J. Katz (Eds.), Joining and leaving religion: Research perspectives (pp. 269-285). Leominster: Gracewing.

Stiles, W.B. (2005). Case studies. In J.C. Norcross, L.E. Beutler, \& R.F. Levant (Eds.), Evidence-based practices in mental health: Debate and dialogue on the fundamental questions (pp. 57-64). Washington, DC: American Psychological Association.

Valsiner, J. (1989). Human development and culture: The social nature of personality and its study. Massachusetts: Lexington Books.

Valsiner, J. (1998). The guided mind. A sociogenetic approach to personality. Cambridge MA \& London: Harvard University Press.

Valsiner, J., \& Connolly, K.J. (2003). The nature of development: The continuing dialogue of processes and outcomes. In J. Valsiner \& K.J. Conolly (Eds.), Handbook of Developmental Psychology (pp. ix-xviii). London/Thousand Oaks/New Delhi: Sage publications.

Valsiner, J., \& Lawrence, J.A. (1997). Human development in culture across the life span. In J.W Berry, P.R. Dasen, \& T.S. Saraswathi (Eds.), Handbook of cross-cultural psychology (vol. 2, pp. 69-106). Needham Heights: Allyn \& Bacon.

Van Geert, P. (2003). Dynamic system approaches and modeling of developmental processes. In J. Valsiner \& K.J. Conolly (Eds.), Handbook of developmental psychology (pp. 640-672). London/Thousand oaks/New Delhi: Sage publications.

Vygotsky, L.S. (1962). Thought and language. Cambridge, MA: The M.I.T. Press. (Original work published 1934)

West, L. (2006). Managing change and transition. A psychosocial perspective on lifelong learning. In P. Sutherland \& J. Crowther (Eds.), Lifelong learning: Concepts and contexts (pp. 39-47). Oxon/New York: Routledge.

Wiener, W.J. (1993). A monument's moment. The psychology of keeping a diary. In R. Josselson \& A. Lieblich (Eds.), The narrative study of lives (pp. 30-58). Thousand Oaks: Sage.

Zittoun, T. (2004). Preapprenticeship as a transitional space. In A.-N. Perret-Clermont, C. Pontecorvo, L. Resnick, T. Zittoun, \& B. Burge (Eds.), Joining society: Social interaction and learning in adolescence and youth (pp. 153176). Cambridge/New York: Cambridge University Press.

Zittoun, T. (2006a). Insertions. A quinze ans, entre échecs et apprentissage [Insertions. Being fifteen, from failure to apprenticeship]. Berne: Peter Lang.

Zittoun, T. (2006b). Transitions. Development through symbolic resources. Coll. Advances in Cultural Psychology: Constructing Development. Greenwich (CT): InfoAge.

Zittoun, T. (2006c). Difficult secularity: Talmud as symbolic resource. Outlines, 2, 59-75.

Zittoun, T., Aveling, E.-L., Gillespie, A., \& Cornish, F. (in press). People in transitions in worlds in transition: Ambivalence in the transition to womanhood during WWII. In A.C. Bastos, K. Uriko, \& J. Valsiner (Eds.), Cultural dynamics of women's lives. Trieste: Carlo Amore. 
Zittoun, T., Cornish, F., Gillespie, \& Aveling, E.-L. (2008). Using social knowledge: A case study of a diarist's meaning making during World War II. In W. Wagner, T. Sugiman, \& K. Gergen (Eds.), Meaning in action: Constructions, narratives and representations (pp. 163-179). New York: Springer.

Zittoun, T., Gillespie, A., Cornish, F., \& Psaltis, C. (2007). The metaphor of the triangle in theories of human development. Human Development, 50, 208-229.

Zittoun, T., Duveen, G., Gillespie, A., Ivinson, G., \& Psaltis, C. (2003). The uses of symbolic resources in transitions. Culture \& Psychology, 9(4), 415-448.

Cet article présente deux modèles pour analyser les transitions éducatives. Premièrement, des transitions sont des processus de changement qui suivent des ruptures perçues par les personnes. Ils comprennent des processus d'apprentissage, de changement identitaire et de construction de signification. Deuxièmement, ces processus peuvent être observés au travers d'un prisme sémiotique, qui articule la personne, autrui, l'objet et le sens de l'objet pour la personne, situés dans un cadre social spécifique. Les transitions sont comprises comme des reconfigurations de ce prisme. Le rôle des institutions en tant que cadres sociaux qui peuvent faciliter ou contraindre ces reconfigurations est mis en évidence. Trois études de cas de transitions - vers la formation professionnelle, hors d'une école religieuse, et vers le travail en temps de guerre - soutiennent cette proposition.

Key words: Development, Institutions, Ruptures, Symbolic resources, Transitions.

Received: July 2006

Revision received: January 2007

Tania Zittoun. Professor, Institut de Psychologie et Education, FLSH, Université de Neuchâtel, Louis Agassiz 1, CH-2000 Neuchâtel, Switzerland. Tel.: +41(0)327181989; Fax: +41(0)327181851; E-mail: tania.zittoun@unine.ch; Web site: www2.unine.ch/ipe

Current theme of research:

I am interested in the way in which people can use the cultural elements that society makes available to solve the demands of their daily lives, in or out of formal settings. On the one hand, what sorts of social interactions, dynamics of recognition, institutional discourse, or social representations of knowledge can facilitate or limit such uses? On the other hand, what sorts of personal resonance should these elements have to be used? I am currently leading a research project funded by the Swiss National Foundation (together with M. Grossen, and O. Lempen, C. Matthey, \& S. Padiglia) to study how adolescents in vocational and pre-university secondary schools can use philosophy and literary texts met at school as resources for addressing daily issues.

Most relevant publications in the field of Psychology of Education:

Zittoun, T. (2004). Preapprenticeship as a transitional space. In A.-N. Perret-Clermont, C. Pontecorvo, L. Resnick, T. Zittoun, \& B. Burge (Eds.), Joining society: Social interaction and learning in adolescence and youth (pp. 153176). Cambridge/New York: Cambridge University Press.

Zittoun, T. (2006a). Insertions. A quinze ans, entre échecs et apprentissage [Insertions. Being fifteen, from failure to apprenticeship]. Berne: Peter Lang.

Zittoun, T. (2006b). Transitions. Development through symbolic resources. Coll. Advances in Cultural Psychology: Constructing Development. Greenwich (CT): InfoAge. 
Zittoun, T. (2007). The role of symbolic resources in human lives. In J. Valsiner \& A. Rosa (Eds.), Cambridge handbook of socio-cultural psychology (pp. 343-361). Cambridge: Cambridge University Press.

Zittoun, T., \& Perret-Clermont, A.-N. (in press). Four social psychological lenses for psychology of learning and development. European Journal of Psychology of Education. 